\title{
PERATURAN KESEHATAN INTERNASIONAL 2005: PERKEMBANGAN SUBSTANSIAL UNTUK HUKUM INTERNASIONAL DAN KEAMANAN KESEHATAN GLOBAL ${ }^{1}$
}

\author{
Rika Kurniaty \\ Fakultas Hukum, Universitas Brawijaya \\ Jalan Veteran, Malang, Indonesia, 65145 \\ rika_kurniaty@ub.ac.id
}

\begin{abstract}
This article elaborates IHR 2005 as the umbrella rule for handling infectious diseases across the world. Globalization and the existence of emerging and re-emerging infectious diseases that do not recognize national boundaries become a driving factor for the establishment of global health security. The international community has long recognized the need for international collaboration to control the spread of infectious diseases across national borders. Under the World Health Organization, many countries have drafted a collective agreement to reduce the risk of expanding transmission through the International Health Regulation (IHR 2005). IHR 2005 is the result of the IHR 1969 revision. The World Health Assembly adopted the 2005 IHR as an international treaty that binds member countries. The 2005 IHR regulates the main substantive changes of the previous regime and has the principle of respecting human rights and controlling infectious diseases without having hampering travel and trade proportionally.
\end{abstract}

Keywords: International Health Regulation 2005; Global Health Security; World Health Organization; Human Rights.

\begin{abstract}
Abstrak
Artikel ini membahas IHR 2005 sebagai aturan umum untuk menangani penyakit menular. Munculnya ancaman emerging maupun re-emerging infectious diseases dan globalisasi penyakit yang tidak mengenal batas wilayah menjadi faktor pendorong pentingnya perhatian terhadap keamanan kesehatan global. Masyarakat internasional telah lama menyadari perlunya kolaborasi dan tata kelola internasional untuk mengendalikan penyebaran penyakit menular yang mampu melalui lintas batas Negara. Dibawah Organisasi Kesehatan Dunia, negara-negara anggota PBB telah merancang sebuah kesepakatan bersama untuk mengurangi resiko perluasan penularan melalui Peraturan Kesehatan Global (International Health Regulation 2005) yang merupakan hasil revisi peraturan tahun 1969. Majelis Kesehatan Dunia mengadopsi IHR 2005 sebagai perjanjian internasional yang mengikat negara anggota. IHR 2005 mengatur perubahan substantif utama dari rezim sebelumnya, dan memiliki prinsip penghormatan HAM, dan pengendalian penyakit menular tanpa harus menghambat perjalanan dan perdagangan secara proporsional.
\end{abstract}

Kata Kunci: Peraturan Kesehatan Internasional 2005; Keamanan Kesehatan Global; Organisasi Kesehatan Dunia; HAM.

\footnotetext{
${ }^{1}$ Artikel ini merupakan hasil penelitian yang didanai oleh LPPM Universitas Brawijaya melalui DIPA 2020 dalam rangka kompetisi hibah Guru Besar dan Doktor.
} 


\section{A. Pendahuluan}

Pandemi global yang muncul dalam beberapa dasawarsa terakhir (Wabah Pes, flu Spanyol, dan Covid-19) menjadi fokus masyarakat internasional. Pandemi Covid-19 yang dihadapi negara-negara di dunia pada saat ini menjadi permasalahan serius karena mengganggu kesehatan masyarakat dan stabilitas negara (Tobing, 2020), khususnya dalam aspek ekonomi. Covid-19 ditetapkan sebagai peristiwa darurat keamanan kesehatan global oleh Organisasi Kesehatan Dunia (World Health Organization, WHO) yang bertindak sebagai koordinator kesehatan umum internasional (World Health Organization, 2020).

Dalam komunitas internasional kesehatan dikategorikan sebagai hak dasar setiap orang yang harus dilindung. Melalui Perserikatan Bangsa-Bangsa (PBB), negaranegara pada tahun 1948 telah menetapkan Universal Declaration of Human Rights, yang di dalamnya mengatur hak atas kesehatan. Pasal 25 menyatakan bahwa: "Everyone has the right to a standard of living adequate for the health and wellbeing of himself and of his family, including food, clothing, housing and medical care and necessary social services, and the right to security in the event of unemployment, sickness, disability, widowhood, old age or other lack of livelihood in circumstances beyond his control."

Hak dalam pasal 25 tersebut terkait dengan pengakui bahwa kesehatan semua orang adalah dasar untuk pencapaian perdamaian dan keamanan.

Guna menjamin keamanan kesehatan, Majelis Kesehatan Dunia (World Health Assembly, WHA) sebagai organ dibawah WHO, mengadopsi Peraturan Kesehatan Internasional 2005 atau Internasional Health Regulations 2005 (selanjutnya disebut IHR 2005 pada artikel ini) pada 23 Mei 2005 (Plotkin B, 2007). IHR 2005 mewakili langkah kritis perbaikan dalam melindungi keamanan kesehatan masyarakat global (Baker, 2006). IHR 2005 merupakan puncak dari proses revisi selama satu dekade dan perkembangan penting bagi hukum internasional dan kesehatan masyarakat global. IHR 2005 muncul pada saat kesehatan masyarakat, keamanan, dan demokrasi telah menjadi hal yang saling terkait serta menjadi persoalan internasional.

IHR 2005 merupakan satu-satunya perjanjian hukum internasional yang secara eksplisit mengatur kewajiban negara kepada masyarakat internasional tentang penyebaran penyakit menular. IHR 2005 menjadi upaya reformasi hukum internasional yang sering menjadi polemik dan diawasi secara ketat sejak pecahnya Sindrom Pernafasan Akut (SARS) pada tahun 2003 di Cina dan beberapa negara lain (Fidler, 2008). Pakar kesehatan masyarakat berpendapat bahwa IHR baru sangat dibutuhkan untuk membantu melindungi masyarakat global dari berbagai penyakit menular. Hal ini terkait dengan dengan kekhawatiran tentang potensi wabah flu burung di Asia yang dipicu oleh penularan dari manusia ke manusia (Angus, 2005).

Hukum internasional terkait kesehatan masyarakat telah mengalami inovasi dan perubahan signifikan di masa lalu, termasuk pengembangan hak asasi manusia internasional atas kesehatan, pertumbuhan hukum lingkungan internasional dan pembentukan Organisasi Perdagangan Dunia (WTO) (Widagdo, 2019). IHR 2005 merupakan salah satu perubahan paling radikal dan jauh dalam hukum internasional tentang kesehatan masyarakat sejak awal kerjasama kesehatan internasional pada pertengahan abad ke-19. IHR 2005 mengatur bagaimana negara-negara anggota dan WHO secara kolektif menangani penyebaran penyakit global dan menghindari gangguan yang tidak perlu dengan lalu lintas dan perdagangan internasional. IHR 2005 WHO untuk bertindak sebagai institusi pusat dari semua informasi pengawasan penyakit yang diperlukan, dan merinci keadaan di mana negara memiliki kewajiban hukum untuk melaporkan wabah penyakit ke seluruh dunia (Aktieva, 2013).

Analisa IHR 2005 terhadap keamanan kesehatan global merupakan hal yang 
signifikan, karena pada akhir abad 20 hingga sekarang pandemi penyakit menular dan masalah keamanan kesehatan global menjadi ancaman banyak negara dan lebih sering muncul dalam agenda forum internasional. Termasuk juga adanya fenomena penyebaran Covid-19 yang menjadi tantangan kesehatan dan perekonomian hampir di semua negara di dunia saat ini. IHR 2005 dan isu kesehatan global sangat penting dan relevan untuk dibahas dan dikaji di era sekarang. Namun studi-studi terkait IHR sebagai salah perjanjian internasional yang mengikat negara-negara angota masih sedikit dikaji, khususnya di Indonesia.

\section{B. Metode Penelitian}

Metode yang digunakan dalam studi ini adalah Yuridis Normatif. Penelitian ini bermaksud untuk mengkaji implemantasi dari International Health Regulation 2005 terkait perlindungan keamanan kesehatan global. Penelitian ini menggunakan teknik pengumpulan data berdasarkan studi dokumentasi dan studi pustaka (library research) dengan cara mengumpulkan data dan informasi dari berbagai sumber dokumen dan literatur.

Data primer dalam studi ini adalah data yang diperoleh melalui dokumen-dokumen resmi/literatur-literatur yang sesuai dengan permasalahan terkait global health security dan hak asasi manusia yang diperoleh melalui bahan-bahan kepustakaan. Data primer dalam penelitian ini meliputi: International Health Regulations (1969); International Health Regulations (2005); Deklarasi Universal Hak Asasi Manusia 1948; The Charter of the United Nations 1945; UU No. 39 Th 1999 tentang Hak Asasi Manusia; dan Vienna Convention on the Law of Treaties.

\section{Hasil dan Pembahasan}

\section{Perkembangan Gagasan Keamanan Kesehatan Internasional}

\section{a. Peraturan Sanitasi Internasional: Awal kolaborasi}

Masyarakat internasional telah lama menyadari perlunya kolaborasi dan tata kelola internasional untuk mengendalikan penyebaran penyakit menular. Pada era 1800-an, perjanjian dan diskusi internasional berfokus pada pada penyakit tertentu (kolera, wabah, dan demam kuning). Negara-negara pada masa itu masih berpusat pada peraturan karantina yang diperlukan untuk mencegah penyakit menular melintasi perbatasan internasional melalui perdagangan dan pengangkutan. Sebelum dimulainya kerjasama internasional mengenai penyebaran penyakit menular tersebut, masingmasing negara menegakkan kebijakan nasional melalui karantina kapal dan pendatang. Karantina kapal dan pendatang tersebut merupakan respons kebijakan nasional yang hampir universal terhadap ancaman penyakit impor (Davies, 2015) .

Pertemuan konferensi sanitasi internasional pertama pada tahun 1851 mencerminkan kesimpulan dari negaranegara Eropa utama bahwa penyebaran penyakit menular internasional tidak lagi dapat ditangani sebagai masalah pemerintahan nasional saja. Masalah penyakit yang menyebar lintas perbatasan melalui perdagangan dan perjalanan internasional menuntut kerja sama internasional. Konvensi Sanitasi Internasional tahun 1893 mengungkapkan tujuan tersebut dalam pernyataan pembukaan bahwa Negaranegara telah memutuskan untuk menetapkan langkah-langkah umum untuk melindungi kesehatan masyarakat selama epidemi kolera tanpa menghalangi transaksi komersial dan lalu lintas penumpang secara sia-sia.

Pendekatan kerjasama internasional untuk penyakit menular dimulai pada pertengahan abad ke-19 ketika negaranegara Eropa berjuang untuk mengatasi gelombang kolera epidemi yang datang 
berturut-turut. Wabah tersebut tidak hanya menyebabkan penularan dan mortalitas yang serius di seluruh Eropa tetapi juga meningkatkan beban pada arus perdagangan internasional. Motivasi pendorong adanya kerja sama kesehatan internasional pada akhir abad ke-19 dan awal abad ke-20 adalah untuk melindungi Eropa dan Amerika Utara dari impor dan penyebaran "penyakit Asia" (Fidler, 2008). Tiga penyakit besar menular - kolera, wabah, dan demam kuning - adalah penyakit yang tidak dianggap berasal dari Eropa dan Amerika Utara dan menyebar dari wilayah selatan, non-Eropa ke Utara. Dengan demikian, perhatian mendasar adalah mengurangi beban pada perdagangan Eropa dan Amerika Utara yang diciptakan sebagai tanggapan nasional atas ancaman impor "penyakit Asia". Dibuatnya perjanjian tentang pengendalian penyakit menular tidak hanya melibatkan masalah tradisional perdagangan laut, perjalanan dan karantina tetapi juga perluasan ke navigasi udara karena teknologi transportasi ini muncul pada paruh pertama abad kedua puluh.

Diskusi dan negosiasi mengenai penyakit menular dikodifikasi ke dalam Konvensi Sanitasi Internasional Pertama tahun 1892. Pada tahun 1969, peraturan tersebut direvisi dan diganti namanya menjadi Peraturan Kesehatan Internasional (IHR). Kemudian WHA mengubah IHR dan menghilangkan cacar dari daftar penyakit yang tunduk pada Peraturan tersebut di tahun 1981. Amandemen IHR ini mewakili perubahan stagnasi pengaturan kesehatan internasional sebelumnya. ISR dan IHR 1969, walau sedikit, berkontribusi terhadap pemberantasan cacar global. Pemberantasan cacar global tersebut menjadi salah satu pencapaian kesehatan masyarakat terbesar dalam perlindungan kesehatan manusia.

\section{b. Pendirian Organisasi Kesehatan Dunia dan Hak Asasi kesehatan}

Perjanjian internasional tentang pengendalian penyakit menular yang lama membuktikan bahwa kerjasama internasional dalam bidang kesehatan tidak cukup hanya tambal sulam dari kebiasaan interansional lama, tetapi harus mengatur juga masalah prosedural. Proses berbeda dalam mengadopsi dan mengubah hukum internasional mengenai kontrol penyakit menular diperlukan; dan Konstitusi WHO yang mulai berlaku pada tahun 1948 membuka peluang untuk proses baru tersebut. Di bawah Konstitusi WHO, Mejelis Kesehatan diberi wewenang untuk mengadopsi peraturan tentang persyaratan sanitasi, karantina, dan prosedur lain yang dirancang untuk mencegah penyebaran penyakit internasional (Pasal 21(a) Konstitusi WHO). Peraturan tersebut mengikat Negara-negara Anggota WHO kecuali mereka menolaknya (Pasal 22, Konstitusi WHO)

Pendirian WHO juga berarti bahwa seperangkat aturan penyakit menular akan dikelola oleh satu organisasi kesehatan internasional dengan keanggotaan universal hampir seluruh negara-negara yang ada. Pendirian WHO membawa pandangan baru tentang kerjasama kesehatan internasional. Perubahan prosedural yang dipengaruhi oleh Konstitusi WHO menciptakan kemungkinan bagi WHO untuk mengadopsi satu set aturan hukum internasional untuk menggantikan tambal sulam konvensi sanitasi internasional yang lalu. Selain itu, Konstitusi WHO memastikan bahwa seperangkat aturan akan diterapkan secara luas dalam sistem internasional. Pembukaan Konstitusi WHO mengungkapkan visi baru ini. Tiga prinsip pertama memberikan pengertian tentang bagaimana pandangan tersebut ini berbeda dari tujuan pengaturan kesehatan 
sebelumnya, sebagaimana tertulis dalam bagian pembukaan bahwa: 1) Kesehatan adalah kondisi fisik, mental, dan sosial yang lengkap dan bukan sekadar tidak adanya penyakit atau kelemahan; 2) Menikmati standar kesehatan tertinggi yang dapat dicapai adalah salah satu hak dasar setiap manusia tanpa membedakan ras, agama, kepercayaan politik, kondisi ekonomi atau sosial; dan 3) Kesehatan semua orang adalah dasar untuk mencapai kedamaian dan keamanan, dan bergantung pada kerja sama penuh individu dan Negara.

Pembukaan Konstitusi WHO menyatakan bahwa standar kesehatan tertinggi adalah hak asasi manusia yang mendasar (World Health Organization, 2006). Pernyataan ini menandai dimulainya pengembangan dalam hukum hak asasi manusia internasional tentang "hak atas kesehatan", yang muncul dalam Kovenan Internasional tentang Hak-Hak Ekonomi, Sosial dan Budaya/ ICESCR 1966. Dalam hal ekonomi internasional, pengembangan kerangka kerja multilateral untuk perdagangan barang dalam Kesepakatan Umum tentang Tarif dan Perdagangan (GATT) pada tahun 1947 memicu pergeseran ke GATT sehubungan dengan perimbangan perdagangan dan kesehatan masyarakat. GATT termasuk pengecualian umum yang memungkinkan pihak kontraktor untuk melanggar kewajiban GATT jika pelanggaran tersebut diperlukan untuk melindungi kehidupan manusia atau kesehatan.

Aturan GATT yang diterapkan pada perdagangan yang membatasi tindakan kesehatan yang diadopsi untuk mengatasi ancaman dari penyakit menular dan tidak menular, membuat ruang lingkup kesehatan publik GATT menjadi luas.

Disamping itu, munculnya minat dalam perlindungan lingkungan internasional pada 1960-an dan 1970-an (Konferensi Stockholm tentang
Lingkungan Manusia pada tahun 1972) membantu menghasilkan hukum internasional baru yang relevan dengan perlindungan kesehatan manusia. Negara-negara merundingkan perjanjian polusi laut dan polusi udara lintas batas jarak jauh (Konvensi terkait Intervention on the High Seas in Cases of Oil Pollution Casualties, 29 November 1969 dan Konvensi for the Prevention of Marine Pollution by Dumping of Wastes and Other Matter, 29 December 1972) yang berupaya mengurangi ancaman bentuk-bentuk polusi tersebut bagi kesehatan manusia dan lingkungan.

\section{c. Perbaikan Aturan Kesehatan Internasional}

Sebagaimana paparan sebelumnya, Konvensi Sanitasi Internasional (International Sanitary Regulation, ISR) direvisi dan diganti namanya menjadi Peraturan Kesehatan Internasional pada tahun 1969. IHR 1969 dimaksudkan untuk memperkuat penggunaan prinsip-prinsip keamanan kesehatan sebagaimana diterapkan secara internasional, untuk mendeteksi, mengurangi atau menghilangkan sumber dari mana infeksi menyebar. Juga untuk meningkatkan sanitasi di/dan sekitar pelabuhan, dan bandara. IHR 1969 juga bertujuan untuk mencegah penyebaran penyakit dan untuk mendorong kegiatan epidemiologi di tingkat nasional. Perjanjian yang tertuang dalam IHR 1969 tersebut membahas kewajiban negara yang terletak pada kapasitas untuk melaporkan penyakit tertentu (seperti kolera ke WHO) dan mempertahankan kemampuan kesehatan masyarakat minimal di pelabuhan dan perbatasan (Nadilla, 2020).

Seiring waktu, kepatuhan terhadap peraturan IHR 1969 berkurang, sebagian karena negara melihat manfaat terbatas bagi kepentingan nasional dari persyaratan pelaporan penyakit. 
Relevansi dan efektivitas sistem pengawasan global di bawah IHR 1969 secara bertahap memudar. Pada tahun 1990-an, konsensus muncul di antara komunitas kesehatan global bahwa muncul ancaman kesehatan yang baru (misalnya virus Ebola) dan penyakit menular yang muncul kembali (seperti demam berdarah) (Gostin LO., 2004). Emerging dan re-emerging desease akan meningkat di periode mendatang. Globalisasi yang berjalan sangat cepat memfasilitasi penyebaran penyakitpenyakit tersebut melewati batas negara. Regulasi yang ada dianggap tidak memberi jawaban, baik dalam pengawasan atau tanggapan terhadap penyakit (seperti meningkatnya krisis HIV / AIDS internasional). Alat yang tersedia untuk mengatur respons internasional terhadap wabah lintasperbatasan tidak memadai, sehingga para negara-negara dibawah WHO memandang perlu adanya amandemen terhadap IHR 1969.

Secara singkat, masalah utama perlunya revisi IHR terkait: (1) terbatasnya jumlah penyakit menular yang tunduk pada IHR; (2) kegagalan Negara-negara Pihak untuk memberi tahu WHO tentang wabah penyakit yang dapat diberitahukan; dan (3) kegagalan Negara-negara Pihak untuk mematuhi langkah-langkah maksimum yang dapat mereka terapkan pada perdagangan dan perjalanan yang datang dari negara-negara yang menderita wabah penyakit yang tunduk pada IHR.

\section{d. SARS Sebagai Momentum Proses Revisi IHR}

Wabah Sindrom Pernafasan Akut/ SARS yang terjadi pada tahun 2003 menjadi faktor pedorong utama untuk mewujudkan dan mengimplementasikan revisi IHR 1969. Meskipun WHO telah menerbitkan Draft IHR sementara pada bulan Januari 1998 dan meskipun telah memproduksi naskah teks untuk tinjauan internal sejak tanggal itu, baru pada Januari 2004 WHO mengeluarkan proposal lengkap untuk IHR baru. Untuk mewujudkan perubahan IHR, WHO terlibat dalam konsultasi regional dan menjadi tuan rumah sesi negosiasi antar pemerintah mengenai proposal revisi IHR pada November 2004. Negosiasi tersebut dihadiri lebih dari 500 delegasi dari lebih dari 150 Negara Anggota WHO. Semua kegiatan dalam waktu satu tahun tersebut menggambarkan bagaimana WHO bertindak untuk memanfaatkan momentum untuk revisi IHR yang distimulasi oleh wabah SARS.

Negosiasi terwujudnya revisi peraturan kesehatan tersebut berlangsung cukup panjang. Para delegasi negosiasi antar pemerintah pada November 2004 belum menyetujui draf akhir dari IHR yang direvisi. WHO menjadwalkan sesi negosiasi kedua untuk akhir Februari 2005. Negosiasi antar pemerintah di bulan Februari membuat kemajuan tetapi juga tidak dapat menyelesaikan revisi IHR. Sesi negosiasi lainnya harus dijadwalkan pada pertengahan Mei 2005 guna menyelesaikan revisi IHR untuk diadopsi pada pertemuan tahunan WHA pada akhir Mei. Salah satu masalah sulit yang memperpanjang negosiasi revisi IHR karena melibatkan ketentuan yang diusulkan mengenai keharusan Negaranegara Pihak untuk memberikan semua informasi kesehatan masyarakat yang relevan, bahan-bahan dan sampel untuk keperluan verifikasi dan tanggapan jika Negara-negara Pihak memiliki bukti pelepasan yang disengaja dari agen biologis, kimia atau radiologis di dalam wilayah mereka (Burkle, 2015). Persyaratan semacam itu menghubungkan proses revisi IHR dengan politik sensitif dan kontroversial mengenai senjata pemusnah massal (Weapon of Mass Destruction, WMD). Beberapa negara, terutama Amerika Serikat, menginginkan IHR yang 
direvisi untuk memasukkan persyaratan seperti itu. Negara-negara lain, seperti Brasil dan Iran, berpendapat persyaratan dihapus dari IHR yang direvisi (Angus, 2005). Setelah negosiasi sulit, para delegasi akhirnya mencapai kesepakatan pada tanggal 14 Mei 2005. WHA akhirnya mengadopsi Regulasi Kesehatan Internasional Revisi, yang dikenal sebagai IHR 2005. IHR 2005 ini mengikat 194 Negara, termasuk semua Negara Anggota WHO.

\section{Implementasi IHR 2005}

\section{a. Ruang Lingkup dan Tujuan IHR 2005}

IHR 2005 mulai berlaku pada 2007, meskipun Negara-negara Anggota WHO sepakat untuk memulai implementasi sukarela pada Mei 2006. Negara-negara memiliki waktu memulai penilaian kapasitas inti mereka hingga Juni 2009, dan memiliki waktu hingga 2012 untuk mencapai kepatuhan penuh. Salah satu tema yang tetap konsisten selama proses revisi IHR adalah kebutuhan untuk memperluas ruang lingkup aplikasi IHR. Ruang lingkup tersebut meliputi kerangka kerja dan peralihan pendekatan khusus dalam merespon ancaman kesehatan masyarakat dalam jumlah yang lebih besar dan lebih luas, termasuk ancaman penyakit yang tidak diperkirakan sebelumnya. Tema perluasan ruang lingkup yang direvisi tersebut juga mencakup tujuan IHR 2005, peningkatan sumber informasi pengawasan yang tersedia bagi WHO, sifat kewajiban yang harus dilakukan oleh Negara-negara Pihak IHR, wewenang dan tanggung jawab WHO dalam pengawasan dan respons, dan penggabungan. prinsip-prinsip hak asasi manusia.

IHR 2005 berisi lima perubahan substantif utama dari rezim sebelumnya, yaitu: (1) perluasan signifikan cakupan IHR; (2) penciptaan kewajiban pada
Negara-negara untuk mengembangkan kapasitas pengawasan dan tanggapan inti minimum; (3) memberi WHO wewenang untuk mengakses dan menggunakan sumber informasi pengawasan nonpemerintah; (4) memberi WHO kekuatan untuk menyatakan keberadaan keadaan darurat kesehatan publik yang menjadi perhatian internasional dan mengeluarkan rekomendasi tentang bagaimana Negara-negara Pihak harus menangani keadaan darurat semacam itu dan risiko kesehatan masyarakat rutin; dan (5) penggabungan konsepkonsep HAM ke dalam implementasi IHR oleh Negara-negara Pihak. Perubahan tersebut dapat dilihat di tabel 1.

Maksud dan ruang lingkup IHR 2005 adalah untuk mencegah, melindungi, mengendalikan, dan memberikan respons kesehatan masyarakat terhadap penyebaran penyakit internasional dengan cara yang sesuai dan terbatas pada risiko kesehatan masyarakat, serta menghindari gangguan yang tidak perlu dengan lalu lintas dan perdagangan internasional. Ketentuan ini sejalan dengan tujuan IHR 1969: keamanan maksimum terhadap penyebaran penyakit internasional dengan gangguan minimum pada perdagangan dan perjalanan dunia. Meskipun ada kesamaan tujuan antara IHR lama dan baru, kesamaannya tidak boleh mengaburkan ruang lingkup IHR yang baru diperluas (Plotkin B, 2007).

Disamping itu, IHR 2005 memperluas ruang lingkup dengan melibatkan prinsip-prinsip HAM. IHR 2005 mensyaratkan bahwa peraturan tersebut harus diimplementasikan dengan rasa hormat penuh terhadap martabat, hak asasi manusia dan kebebasan mendasar manusia. Sejumlah ketentuan dalam IHR 2005 berisi ketentuan revisi dengan mendukung penerapan prinsip umum yang 
menghormati martabat, hak asasi manusia, dan kebebasan mendasar manusia lainnya. (lihat Tabel 2).

Ketentuan tersebut di atas menimbulkan pertanyaan apakah IHR 2005 sesuai dengan prinsip-prinsip HAM internasional yang ada. Agar suatu tindakan kesehatan masyarakat yang membatasi hak sipil dan politik dianggap sah, tindakan tersebut harus (1) menanggapi kebutuhan publik atau sosial yang mendesak; (2) mengejar tujuan yang sah; (3) proporsional dengan tujuan yang sah; dan (4) tidak lebih ketat dari yang diperlukan untuk mencapai tujuan yang dicari dengan membatasi hak. Pengukuran pembatasan hak juga harus dilaksanakan dengan cara yang tidak diskriminatif (sesuai Kovenan Internasional tentang Sipil dan Hak Asasi Manusia) (Kurniaty, 2020). Individu yang dirampas kebebasannya harus diperlakukan dengan kemanusiaan dan menghormati martabat manusia yang melekat (United Nations Human Rights, n.d.)

Tabel 1.

Perbandingan Substansi IHR 2005 dan IHR 169

\begin{tabular}{|c|c|c|c|}
\hline \multicolumn{2}{|c|}{ IHR 2005} & \multicolumn{2}{|c|}{ IHR 169} \\
\hline Bagian (Pasal) & Subjek & Bagian (Pasal) & Subjek \\
\hline Bag. I (1-3) & $\begin{array}{l}\text { Definisi, tujuan dan } \\
\text { ruang lingkup, prinsip } \\
\text { dan otoritas yang } \\
\text { bertanggung jawab }\end{array}$ & Bag. I (1) & Definisi \\
\hline Bag. II (5-14) & $\begin{array}{l}\text { Informasi dan respons } \\
\text { kesehatan masyarakat }\end{array}$ & Bag. II (2-13) & $\begin{array}{l}\text { Pemberitahuan dan } \\
\text { informasi } \\
\text { epidemiologis }\end{array}$ \\
\hline Bag. III (15-18) & Rekomendasi & Bag. III (14-22) & Organisasi kesehatan \\
\hline Bag. IV (19-22) & Tempat masuk & Bag. IV (23-49) & $\begin{array}{l}\text { Tindakan dan } \\
\text { prosedur kesehatan }\end{array}$ \\
\hline Bag. V (23-34) & $\begin{array}{l}\text { Langkah-langkah } \\
\text { kesehatan masyarakat }\end{array}$ & Bag. V (50-75) & $\begin{array}{l}\text { Ketentuan khusus } \\
\text { yang berkaitan dengan } \\
\text { masing-masing } \\
\text { penyakit yang tunduk } \\
\text { pada Peraturan }\end{array}$ \\
\hline Bag. VI (35-39) & Dokumen kesehatan & Bag. VI (76-81) & Dokumen kesehatan \\
\hline Bag. VII (40-41) & Biaya & Bag. VII (82) & Biaya \\
\hline Bag. VIII (42-46) & Ketentuan umum & Bag. VIII (83-85) & Berbagai ketentuan \\
\hline Bag. IX (47-53) & $\begin{array}{l}\text { Daftar Ahli IHR, } \\
\text { Komite Darurat dan } \\
\text { Komite Peninjau }\end{array}$ & Bag. IX (86-94) & Ketentuan akhir \\
\hline Bag. X (54-66) & Ketentuan akhir & & \\
\hline
\end{tabular}


Tabel 2.

Ketentuan IHR 2005 yang Relevan dengan Perlindungan Hak Asasi Manusia

\begin{tabular}{ll}
\hline Pasal & Subjek \\
\hline 3.1 & IHR yang baru harus dilaksanakan dengan rasa hormat penuh terhadap martabat, hak \\
& asasi manusia, dan kebebasan mendasar bagi setiap orang
\end{tabular}

23.2 Atas dasar bukti risiko kesehatan masyarakat, Negara-negara Pihak dapat menerapkan langkah-langkah kesehatan tambahan untuk wisatawan, termasuk pemeriksaan medis yang paling tidak mengganggu dan invasif yang akan mencapai tujuan kesehatan masyarakat untuk mencegah penyebaran penyakit internasional.

23.3 Tidak ada pemeriksaan medis, vaksinasi, profilaksis atau tindakan kesehatan yang boleh dilakukan pada wisatawan tanpa persetujuan tertulis sebelumnya, kecuali dalam situasi di mana langkah-langkah wajib dijamin

23.4 Wisatawan yang akan divaksinasi atau ditawarkan profilaksis harus diberitahu tentang risiko apa pun yang terkait dengan vaksinasi atau non-vaksinasi dan dengan penggunaan atau tidak digunakannya profilaksis

23.5 Setiap pemeriksaan medis, prosedur medis, vaksinasi atau profilaksis lain yang melibatkan risiko penularan penyakit harus dilakukan atau diberikan hanya sesuai dengan pedoman dan standar keselamatan nasional atau internasional yang telah ditetapkan.

31.1 Pemeriksaan medis invasif, vaksinasi, atau profilaksis lainnya tidak diperlukan dari setiap wisatawan kecuali dalam keadaan yang ditentukan dalam IHR baru

31.2 Negara-negara Pihak dapat menerapkan langkah-langkah kesehatan wajib terhadap wisatawan jika ada bukti risiko kesehatan masyarakat yang akan segera terjadi; setiap pemeriksaan medis wajib akan menjadi pemeriksaan yang paling tidak invasif dan mengganggu yang akan mencapai tujuan kesehatan masyarakat

Dalam menerapkan langkah-langkah kesehatan, Negara-negara Pihak harus memperlakukan para wisatawan dengan menghormati martabat, hak asasi manusia dan kebebasan dasar mereka dan meminimalkan segala ketidaknyamanan atau kesulitan yang terkait dengan tindakan-tindakan tersebut, termasuk dengan tidak membedakan masalah gender, sosial budaya, etnis atau agama dari para wisatawan; dan menyediakan makanan dan air yang memadai, akomodasi dan pakaian, perlindungan bagasi, perawatan medis, sarana komunikasi dan bantuan lain yang sesuai bagi para wisatawan yang dikarantina, diisolasi atau dikenai pemeriksaan medis atau prosedur lain untuk tujuan kesehatan masyarakat

42 Tindakan kesehatan yang dilakukan berdasarkan IHR baru harus dimulai dan diselesaikan tanpa penundaan dan diterapkan secara transparan dan tidak diskriminatif

43.2 Langkah-langkah kesehatan tambahan yang memberikan tingkat perlindungan kesehatan yang sama atau lebih besar daripada rekomendasi WHO atau yang sebaliknya dilarang oleh IHR baru tidak boleh lebih invasif atau mengganggu orang daripada alternatif yang tersedia secara wajar yang akan mencapai tingkat perlindungan kesehatan yang sesuai.

45.1 Negara-negara Pihak harus melindungi kerahasiaan informasi yang dapat diidentifikasi secara pribadi yang diterima atau dikumpulkan di bawah IHR yang baru

45.2 Dalam mengungkapkan dan memproses data pribadi untuk keperluan menilai dan mengelola risiko kesehatan masyarakat, Negara-negara Pihak dan WHO harus data tersebut diproses secara adil dan sesuai hukum, relevan dengan tujuan kesehatan masyarakat, akurat dan tetap terbaru dan disimpan tidak lebih lama dari yang diperlukan

45.3 WHO harus menyediakan individu yang meminta data pribadinya dengan akses ke sana dan untuk mengoreksi data tersebut bila perlu 


\section{b. Kebutuhan Pelaporan dan Pengawasan}

Diskusi dalam bagian sebelumnya sudah menyatakan bahwa tujuan IHR 2005 adalah untuk mencegah, melindungi, mengendalikan, dan memberikan respons kesehatan masyarakat terhadap penyebaran penyakit internasional dengan cara yang sepadan dan terbatas pada risiko kesehatan masyarakat, dan menghindari gangguan yang tidak perlu dengan lalu lintas internasional dan perdagangan. Dan salah satu mekanisme agar tujuan tersebut dapat tercapai adalah dengan pelaporan dan pengawasan. IHR 2005 dengan 10 bagian dan 9 lampiran, memiliki beberapa ketentuan utama yang perlu diperhatikan. Pertama dan terutama, ruang lingkup IHR (2005) berkembang melampaui daftar penyakit tertentu untuk memasukkan peristiwa apa pun yang merupakan keadaan darurat kesehatan masyarakat yang menjadi perhatian internasional (public health emergencies of international concern, PHEIC). Kedua, IHR 2005 menekankan pentingnya komunikasi global dan kerjasama untuk deteksi dini dan mitigasi potensial PHEIC. Hal ini termasuk kewajiban bagi setiap negara untuk mengembangkan sarana untuk mendeteksi, melaporkan, dan menanggapi keadaan darurat kesehatan masyarakat.

Untuk itu, IHR 2005 mensyaratkan setiap Negara Anggota untuk membentuk Focal Point IHR Nasional untuk berkomunikasi ke dan dari WHO (baik kantor pusat dan kantor regional), dan memenuhi kapasitas inti untuk pengawasan dan respons penyakit. Pada Juli 2009, 99 persen dari semua Negara Anggota telah menunjuk Focal Point Nasional, tersedia untuk komunikasi dengan Poin Kontak IHR WHO yang ditunjuk 24 jam sehari, 7 hari seminggu. Delapan puluh enam persen dari National Focal Points (NFP) telah mengakses Situs Informasi Acara IHR (situs web aman yang diselenggarakan oleh WHO yang memposting informasi mengenai acara kesehatan masyarakat dan rekomendasi) (Fidler, 2008).

Dibawah mekanisme IHR 2005, negara-negara berkewajiban memberi tahu WHO dalam waktu 24 jam dari penilaian nasional atas peristiwa apa pun yang dapat menimbulkan risiko kesehatan masyarakat bagi Negara lain yang membutuhkan respons dan koordinas internasional. Selanjutnya, WHO akan mengoordinasikan komunikasi lintas negara, memberikan bantuan teknis kepada negara-negara yang merespons, dan bekerja dengan para pakar ilmiah internasional untuk mengembangkan rekomendasi untuk mengurangi konsekuensi dari peristiwa tersebut. IHR 2005 mempertahankan arahan tentang pentingnya menanggapi keadaan darurat kesehatan masyarakat dengan cara yang meminimalkan dampak pada perjalanan dan perdagangan, dan pada saat yang sama menghormati hak asasi manusia para individu. IHR 2005 sangat memperluas otoritas WHO dalam tata kelola global, yang memungkinkan WHO untuk menggunakan sumber informasi eksternal untuk mengidentifikasi kemungkinan PHEIC, membuat penyelidikan otoritas nasional berdasarkan sumber informasi tidak resmi, dan menetapkan rekomendasi walau tanpa adanya kerjasama atau persetujuan dari Negara Anggota yang terkena dampak.

WHO membangun dan menggunakan platform dan strategi baru untuk pengawasan dan tanggapan penyakit menular global. Inti dari strategi tersebut adalah Global Outbreak Alert dan Response Network (GOARN), yang digunakan WHO untuk memperkuat pengawasan global terhadap kejadian penyakit menular. Yang sangat penting bagi berfungsinya GOARN adalah akses WHO ke sumber informasi selain yang diterima dari 
pemerintah. WHO mulai memanfaatkan revolusi dalam teknologi informasi untuk tujuan kesehatan masyarakat global. WHO pertama kali secara informal membangun jaringan peringatan dan respons wabah global pada 1997 dan kemudian meresmikan jaringan tersebut di bentuk GOARN pada tahun 2000. Dukungan kebijakan tingkat tinggi untuk pendekatan baru WHO terhadap pengawasan penyakit menular global datang dari WHA pada Mei 2001, ketika Majelis menyatakan dukungannya untuk kolaborasi antara WHO dan semua mitra teknis potensial. Mitra teknis tersebut termasuk sektor publik yang relevan, organisasi antar pemerintah, organisasi nonpemerintah, dan sektor swasta. Melalui GOARN, WHO secara aktif mencari informasi pengawasan dari semua sumber. Teknologi informasi baru dan penyebaran penyakit secara global mengubah tidak hanya konteks teknologi tetapi juga realitas politik dan ekonomi dari pelaporan penyakit menular (Sedyaningsih, ER., 2008).

Dengan demikian, poin utama dari IHR 2005 adalah mandat yang mengikat secara hukum bahwa Negara Pihak memenuhi persyaratan kapasitas inti minimum untuk deteksi, penilaian, pelaporan, dan respons penyakit. Kegiatan-kegiatan ini dibangun di atas kompetensi inti WHO sebagai instrumen utama tata kelola kesehatan global: menetapkan prioritas dan menetapkan norma untuk membantu otoritas nasional mempersiapkan diri menghadapi krisis kesehatan masyarakat. IHR 2005 memberikan otoritas baru bagi WHO untuk mengumpulkan informasi tentang potensi krisis kesehatan masyarakat dari sumber tidak resmi, dari LSM ke Wabah Global, Peringatan dan Jaringan Respon, dan untuk mengajukan pertanyaan tentang peristiwa langsung ke negara-negara anggota.

\section{c. Efektivitas, Penegakan, dan Dukungan terhadap IHR 2005}

Penerapan IHR 2005 diuji secara kuat untuk pertama kalinya pada peristiwa influenza H1N1 2009. IHR 2005 dikritisi karena kurangnya implemenatasi dalam mekanisme penegakannya. Disatu sisi, semua Negara Anggota secara hukum berkewajiban untuk mengikuti IHR 2005, namun disisi lain tidak ada hukuman formal bagi kegagalan untuk memberi tahu WHO tentang potensi PHEIC, atau untuk kegagalan mencapai kapasitas inti untuk pengawasan, pelaporan dan tanggapan. WHO tidak memiliki kekuatan untuk memaksa negara untuk mematuhi kewajiban IHR 2005.

IHR 2005 tidak memiliki mekanisme penyelesaian sengketa wajib di mana ketidakpatuhan terhadap kewajiban pelaksanaan tindakan kesehatan dalam IHR 2005 dapat diatasi. Ketentuan penyelesaian perselisihan IHR 2005 mensyaratkan penerimaan sukarela oleh Negaranegara Pihak. Dengan demikian, Negara-negara Pihak tidak akan menghadapi "punishment" jika mereka memilih untuk menerapkan langkahlangkah kesehatan yang melanggar IHR 2005, (seperti mengganggu perdagangan internasional atau tidak memberikan penghormatan penuh untuk martabat, hak asasi manusia, dan kebebasan mendasar setiap orang). WHO secara historis lebih bergantung pada rekomendasi dan pedoman yang tidak mengikat untuk Negara-negara Anggotanya daripada menyusun kewajiban yang mengikat secara hukum. Rekam jejak Negara-negara Anggota WHO yang mengadopsi dan mengikuti rekomendasi WHO tidak merata sama sekali. Ketentuan dalam IHR 2005 yang memungkinkan WHO untuk mengeluarkan rekomendasi sementara mungkin tidak menghasilkan 
kepatuhan, dan lebih dilihat sebagai 'soft law' dalam hukum internasional.

IHR 2005 hanya memiliki dampak terbatas kecuali Negara Anggota, terutama negara-negara besar, berkomitmen memberikan modal politik dan ekonomi untuk membuat strategi keamanan kesehatan global dapat bekerja. IHR 2005 memaksakan tugas dan tanggung jawab pada Negara Anggota, dan WHO yang membutuhkan dukungan politik kuat secara berkelanjutan. Keberhasilan penanganan wabah SARS menunjukkan pentingnya dukungan dan komitmen tersebut. Selain itu, membangun infrastruktur nasional dan global untuk menjadikan jaminan kesehatan global menjadi kenyataan memerlukan biaya tinggi, sehingga dibutuhkan investasi ekonomi yang serius dan berkelanjutan di tingkat nasional.

\section{Simpulan}

Implementasi IHR 2005 merupakan peristiwa penting dalam sejarah hukum internasional dan keamanan kesehatan masyarakat. Dalam sejarah kesehatan masyarakat, Konvensi konvensi sanitasi internasional dan IHR 1969 pada perkembangannya tidak mampu mengimbangi pesatnya kemajuan teknologi, pergolakan politik antar negara, dan globalisasi ekonomi yang memecah batas wilayah. IHR 2005 mencoba menjawab tantangan baru, di mana keamanan kesehatan merupakan tantangan tata kelola mendasar bagi semua umat manusia dari tingkat lokal hingga internasional. Keamanan kesehatan global adalah dunia di mana pemerintah, organisasi antar pemerintah, dan aktor non-negara berkolaborasi dalam " cara kerja baru" dengan berkontribusi menuju tujuan bersama melalui sains, teknologi, dan hukum.

IHR 2005 berisi pendekatan untuk pengawasan dan respons penyakit global yang sangat berbeda dari peraturan internasional yang telah ada sebelumnya.
IHR 2005 mengatur bagaimana masyarakat manusia harus memikirkan dan secara kolektif mengatur kerentanan mereka terhadap peristiwa penyakit akut yang serius pada abad ke-21. IHR 2005 mengemukakan perlunya untuk beralih dari pendekatan yang sempit yang berpusat pada negara (tradisional) menuju strategi tata kelola yang diperluas yang mengintegrasikan berbagai ancaman, actor, dan tujuan dalam cara yang universal-fleksibel-dan berwawasan ke depan. Argumen utama keamanan kesehatan global adalah bahwa penyakit akan terus mengancam kesehatan manusia, sehingga tata kelola ancaman penyakit secara efektif diatur didalam IHR 2005 dengan fokus pada keamanan manusia sebagai inti dari dukungan dan operasi. Perlu dicatat bahwa IHR 2005 mengamanatkan pembagian dan koordinasi informasi antar negara, semua tindakan kesehatan masyarakat masih berasal dari masyarakat dan membutuhkan kapasitas pemerintah di tingkat lokal dan nasional. Pandemi Covid-19 yang dihadapi masyarakat sekarang ini dan wabah influenza H1N1 2009 menegaskan kembali bahwa IHR 2005 belum mencapai titik tujuan. Masyarakat internasional perlu mengkaji ulang efektivitas IHR 2005 sebagai respon atau tanggapan atas pandemi penyakit sekarang dan masa mendatang.

\section{DAFTAR PUSTAKA}

Aktieva, T. T. (2013). Masalah Keadilan Pelaksanaan Kewajiban Virus Sharing dalam Sistem IHR. 25(1).

Angus, N. . . et al. (2005). Proposed New International Health Regulations. British Medical Journal, 330.

Baker, M. G. ; D. P. F. (2006). Global public health surveillance under new international health regulations. Emerging Infectious Diseases, 12(7), 1058-1065.

Burkle, F. (2015). Global Health Security Demands a Strong International Health Regulations Treaty and Leadership from 
a Highly Resourced World Health Organization. Disaster Med Public Health Prep, 9(5), 568-580.

Davies, S. E. . A. K.-S. and S. R. (2015). Disease diplomacy: International norms and global health security. JHU Press.

Fidler, D. P. (2008). Influenza Virus Samples, International Law, and Global Health Diplomacy. Emerging Infectious Diseases, 14(1).

Gostin LO. (2004). International infectious disease law: revision of the World Health Organization's International Health Regulations. JAMA, 291(21), 2623-2627. https://doi.org/doi: 10.1001/jama.291.21.2623.

Kurniaty, R. (2020). Democracy and Human Security. Proceedings of the Brawijaya International Conference on Multidisciplinary Sciences and Technology.

https://doi.org/https://doi.org/10.2991/as sehr.k.201021.067

Nadilla, S. (2020). Krisis Covid-19: Perspektif Hukum Internasional Terhadap Pandemi Covid-19 (Crisis: An International Law Perspective to Pandemics). Majalah Hukum Nasional, 50(2).

Plotkin B. (2007). Human rights and other provisions in the revised International Health Regulations (2005). Public Health, 121(11), 840-845.

Sedyaningsih, ER., dkk. (2008). Towards
Mutual Trust, Transparency and Equity in Virus Sharing Mechanism: The Avian Influenza Case of Indonesia. Annals Academic of Medicine, 37(6).

Tobing, S. (2020). Kinerja WHO dalam Sorotan, Apa Perannya selama Pandemi Corona?. Katadata. https://katadata.co.id/sortatobing/berita/ 5ec3a811b500a/kinerja-who-dalamsorotan-apa-perannya-selama-pandemicorona.

United Nations Human Rights. (n.d.). International Covenant on Civil and Political Rights: Adopted and opened for signature, ratification and accession by General Assembly resolution 2200A (XXI) of 16 December 1966 entry into force 23 March 1976, in accordance with Article 49.

Widagdo, S. dkk. (2019). Hukum Internasional Dalam Dinamika Hubungan Internasional. Universitas Brawijaya Press.

World Health Organization. (2006). Constitution of The World Health Organization.

World Health Organization. (2020). Pernyataan Direktur Jenderal tentang Komite Darurat IHR tentang Novel Coronavirus (2019-nCoV). https://www.who.int/dg/ speeches/detail/who-director-general-sstatement-on-ihr-emergencycommitteeon-novel-coronavirus-(2019-nCoV). 